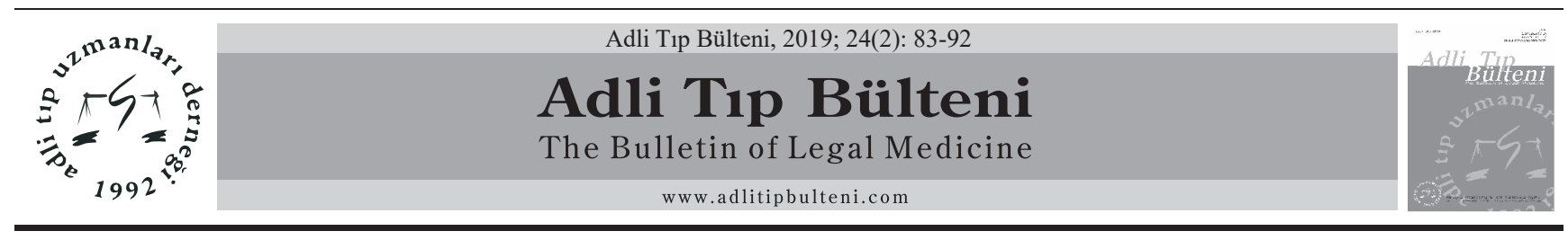

\title{
ARAŞTIRMA / RESEARCH ARTICLE \\ Comparison of Diatoms Which were Obtained from The External Surface of The Body and Internal Organs in the Corpses Pulled Out of Water Using Colloidal Silica Gradient Centrifuge Method
}

\author{
Sudan Çıkarılmış Cesetlerde Kolloidal Silika Gradyen Santrifüj Metodu \\ Kullanılarak Vücudun Dış Yüzeylerinden ve İç Organlardan Elde Edilen \\ Diatomların Karşılaştırılması
}

Çiler Fulya Erkan, Gürsel Çetin*

\begin{abstract}
Objective: Diatom analysis is a valuable tool in forensic science, and it is useful in the diagnosis of drowning and determination of the drowning site. The basic principle of the "diatom test" in investigation of drowning is based on correlation between diatoms are present in the medium where the possible drowning took place and inhalation of water causes penetration of diatoms into the alveolar system and bloodstream and consequently their deposition into brain, kidneys and other organs, like the bone marrow of large bones. There are various extraction methods that are used to isolate diatoms from water and tissues. Nitric acid digestion is a worldwide known method for the extraction of diatoms. In this study, it was aimed to obtain diatom by using colloidal silica centrifuge method instead of acid method besides it was aimed to compare diatom obtained from the external surfaces of body and diatom obtained from the internal organs.

Materials and Methods: Therefore, internal organ and body fluid samples that have been obtained from 30 corpses which were removed from the water and brought to the Council of Forensic Medicine to perform autopsy, were examined and diatom were obtained from samples of 19 cases. Moreover, the diatoms that were obtained from the swab samples taken from the outer body surfaces and the diatoms obtained from the internal organs were compared.

Results: When the diatoms which were obtained from tissues from internal organs and body fluids were evaluated numerically, it was seen that the diatoms that were obtained lungs were in high numbers and it was followed by the pleural liquid, stomach content and pericardial fluid, respectively. The method, which is used, it was possible to obtain plankton other than diatom from the tissues.

Conclusion: According to the findings which were obtained swap samples, more diatoms were obtained from the nasal swap than the other swap samples. Colloidal Silica Gradient Centrifugation Method is more advantageous than traditional Nitric Acid Digestion Method because of that it is nontoxic, reliable, easy to apply and detecting plankton other than diatoms.
\end{abstract}

Keywords: Diatome; Plankton; Percoll.

\section{Öz}

Amaç: Diatom analizi, suda boğulma olgularında ölüm nedeninin ve boğulma ortamının tespitinde kullanılan çok değerli bir araçtır. Diatom analizinin temel prensibi, boğulma ortamında bulunan diatomların, suyun inhalasyonu yolu ile penetrasyonu ve alveollerden genel kan dolaşımına katılarak karaciğer, beyin, kemik iliği gibi iç organlara iletilmesi neticesinde bu organlarda tespit edilmesine dayanır. Diatomların dokulardan ekstraksiyonu için pek çok farklı yöntem kullanılsa da en yaygın olarak kullanılanı dokuların asitle homojenize edilmesi yöntemidir. Bu çalışmada, asit yöntemi yerine, Kolloidal Silika Gradyen Santrifüj yöntemi kullanılarak diatom elde edilmesi amaçlanmış ve yöntemin avantajları tartışılmıștır.

Gereç ve Yöntem: Bu amaçla, Adli Tıp Kurumu'na otopsisi yapılmak üzere getirilen 30 sudan çıkarılan cesetten alınan iç organ ve vücut sıvısı örnekleri incelenmiş ve 19 olguya ait örneklerden diatom elde edilmiştir. Ayrıca belirlenen vücut dış yüzeylerinden alınan sürüntü örneklerinden elde edilen diatomlar ile iç organlardan elde edilen diatomlar karşılaştırılmıştır.

Bulgular: İç organlara ait dokulardan ve vücut sıvılarından elde edilen diatomlar sayısal olarak değerlendirildiğinde en fazla diatomun akciğerden elde edildiği, bunu sırasıyla plevra sıvısı, mide içeriği ve perikard sıvısının takip ettiği görülmüştür.

Sonuç: Elde edilen bulgulara göre, burundan alınan sürüntü örneklerinden, diğer örneklere nazaran daha fazla sayıda diatom elde edilmiştir. Kolloidal Silika Gradyen Santrifüj Yönteminin, geleneksel Nitrik Asit Yöntemine göre, toksik olmaması, güvenilirliği, uygulama kolaylığı ve asit kullanılmadığı için diatom dışındaki planktonun da dokulardan elde edilmesi açısından daha avantajlı olduğu sonucuna varılmıştır.

Anahtar Kelimeler: Diatom; Plankton; Percoll.
DOI: 10.17986/blm.2019252241

Çiler Fulya Erkan: Phd. İstanbul

Üniversitesi-Cerrahpaşa, Adli Tıp

Enstitüsü, Fen Bilimleri Anabilim Dalı, İstanbul

Eposta: cilerfulya@windowslive.com ORCID iD: https://orcid.org/ 0000-0027412-8061

Gürsel Çetin: Prof. Dr., İstanbul

Üniversitesi-Cerrahpaşa, Cerrahpaşa

Tıp Fakültesi, Adli Tıp Anabilim Dalı, İstanbul

Eposta:drgcetin@yahoo.com ORCID iD: https://orcid.org/ 00000002-8183-874X

\section{Bildirimler/ Acknowledgement}

Yazarlar bu makale ile ilgili herhangi bir çıkar çatışması bildirmemişlerdir.

The authors declare that they have no conflict of interests regarding content of this article.

Finansal Destek/Support Resources Bu çalışma İstanbul Üniversitesinin 38022 numaralı projesi ile desteklenmiştir.

This study was funded by Istanbul University with the project number 38022

Received: 14.06 .2018

Revised: 09.08.2018

Accepted: 09.05.2019

p-ISSN: $1300-865 \mathrm{X}$

e-ISSN: 2149-4533 


\section{Introduction}

In the corpses pulled out of the water, as in all forensic cases, an autopsy must be performed in order to determine the cause of death. A detailed internal and external examination and laboratory methods provide important support for differential diagnosis in the evaluation of cases where the cause of death is unknown, and decay develops in the corpses (1). Diatom analysis is a valuable tool in forensic science, and it is useful in the diagnosis of drowning and determination of the drowning site (2). The basic principle of the "diatom test" in investigation of drowning is based on correlation between diatoms are present in the medium where the possible drowning took place and inhalation of water causes penetration of diatoms into the alveolar system and bloodstream and consequently their deposition into brain, kidneys and other organs, like the bone marrow of large bones (3). The diatom test, which is considered as a good compromise tool to reach the conclusion when considered together with the autopsy findings and biochemical findings, is called the gold standard (4). Although many different methods are used for the extraction of diatoms from tissues, the most common method is homogenizing the tissues with acids. This method is inexpensive and easy to take however it takes a long time, the acid to be a toxic substance, phytoplankton and zooplankton around the diatom can be damaged and causes to the prevention of detection are disadvantages of the method. The colloidal silica gradient centrifugation method used in this study is stated that more advantageous because the application time is short, and it does not harm the plankton with its toxic effect (5, $6,7)$.

In this study, it was aimed to obtain diatom by using colloidal silica centrifuge method instead of acid method besides it was aimed to compare diatom obtained from the external surfaces of body and diatom obtained from the internal organs.

\section{Materials and Methods}

In this study, between the date June 2014 and August 2014, 30 corpses pulled out of water, 22 of them from sea (salt water) site and 8 of them from freshwater site, has been fetched to the "Republic of Turkey, Ministry of Justice, Forensic Medicine Institute, Morgue Specialization Department", and samples of tissue, body fluid and swap were examined. Tissue samples of the lung, liver, brain, kidney, bone marrow and samples of gastric fluid, pleural fluid, and pericardial fluid, and swab samples were taken from the mouth, intranasal, external ear canal, hair, toe, fossa axillaris, perineum, and umbilicus were used.
Approximately 1 gr. of tissue samples taken from the internal organs with the aid of a disposable scalpel tip were placed in $15 \mathrm{ml}$ Falcon tubes. $1 \mathrm{ml}$ distilled water was added to homogenize with a homogenizer, after than $8 \mathrm{ml}$ of Percoll was added.

$2 \mathrm{ml}$ samples taken from gastric contents and body fluid samples were placed in $15 \mathrm{ml}$ Falcon tubes and then $8 \mathrm{ml}$ Percoll added.

The tubes were placed in "Beckman Coulter, Allegra $\mathrm{X}-22 \mathrm{R}$ ” centrifuge. It was centrifuged at $12^{\circ} \mathrm{C}$, with $9500 \mathrm{rpm}, 6000 \mathrm{rpm}, 9500 \mathrm{rpm}$, and $6000 \mathrm{rpm}$ respectively, with the period in order to $90 \mathrm{~min}, 15 \mathrm{~min}, 30 \mathrm{~min}$, and $15 \mathrm{~min}$. After each centrifugation, distilled water was added to the tube by removing the upper part. After the last centrifugation, approximately $1 \mathrm{ml}$ of the remained in the bottom of the tube was taken and dripped to the slide. It left to dry in its own case. Entellan was dropped onto the drying slides and closed with a coverslip. After then, prepared preparations were examined in a light microscope after drying.

The cotton part of the swap has been cut and placed in Eppendorf tubes which are sizes $1.5 \mathrm{ml} .1 \mathrm{ml}$ which is containing $30 \%$ Hydrogen Peroxide was added to the

incubator. It was incubated at $70^{\circ} \mathrm{C}$ for 3 hours. Tubes which were taken from the incubator placed in a centrifuge. They were centrifugation at $2400 \mathrm{rpm}$ for 5 minutes. Swaps inside them have been removed. Preparations were prepared as previously described by dropping on the sample slide taken from the bottom of the tube. They were examined by microscope.

\section{Results}

Diatom was detected in 19 of 30 cases. Diatom $(+)$ was detected in 14 of 22 cases which were pulled out of the sea (salt water). Diatom $(+)$ was detected in 5 of 8 cases which were pulled out of fresh water. where the corpses were removed from the water and the obtained plankton is summarized in Table I.

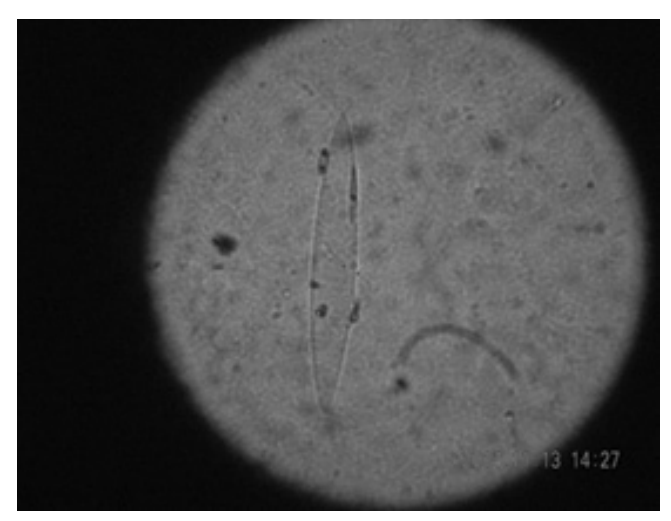

Figure 1. Lung tissue from the case no. 1, Navicula sp. 
Table 1. Where the corpses were removed from the water and the obtained plankton

\begin{tabular}{|c|c|c|c|}
\hline Case No. & $\begin{array}{l}\text { Where the corpses was } \\
\text { located }\end{array}$ & $\begin{array}{l}\text { Feature of } \\
\text { water }\end{array}$ & Obtained plankton \\
\hline 1 & Ergene River & Freshwater & $\begin{array}{l}\text { Cymbella sp., Navicula sp., Pennat diatom, Centric diatom, Dinoflagellate } \\
\text { cyst }\end{array}$ \\
\hline 2 & Üsküdar Pond & Freshwater & \\
\hline 3 & Ergene River & Freshwater & Pennat diatom \\
\hline 4 & Cankurtaran Coast & Sea & Melosira sp., Pennat diatom \\
\hline 5 & Yeşilköy Coast & Sea & Pennat diatom \\
\hline 6 & Akpınar Pond & Freshwater & \\
\hline 7 & Beykoz Coast & Sea & \\
\hline 8 & Uzunköprü Pond & Freshwater & \\
\hline 9 & Şile Coast & Sea & Pennat diatom \\
\hline 10 & Demirköy Pond & Freshwater & Cymbella sp., Amphora sp., Navicula sp., Gomphonema sp., Pennat diatom \\
\hline 11 & Demirköy Pond & Freshwater & Amphora sp., Diatoma sp., Pennat diatom \\
\hline 12 & Kocaali Coast & Sea & Naviula sp., Centric diatom, Pennat diatom \\
\hline 13 & Bolayır Coast & Sea & Pleurosigma sp., Pennat diatom \\
\hline 14 & Yeşilköy Coast & Sea & \\
\hline 15 & Sariyer Coast & Sea & \\
\hline 16 & Kıyıköy Coast & Sea & Pennat diatom \\
\hline 17 & Kıyıköy Coast & Sea & Pennat diatom \\
\hline 18 & Zekeriyaköy Coast & Sea & Navicula sp., Pennat diatom \\
\hline 19 & Vize Coast & Sea & Surirella sp., Pennat diatom \\
\hline 20 & Kıyıköy Coast & Sea & \\
\hline 21 & Kilyos Coast & Sea & Amphora sp., Diploneis sp., Pennat diatom \\
\hline 22 & Gümüşyaka Coast & Sea & Prorocentrum micans, Diploneis sp., Synedra sp., Pennat diatom \\
\hline 23 & Kisırkaya Coast & Sea & Pennat diatom \\
\hline 24 & Gazi Osmanpaşa Coast & Sea & \\
\hline 25 & Arnavutköy Coast & Sea & \\
\hline 26 & Türkeli Coast & Sea & Pennat diatom \\
\hline 27 & Sapanca River & Freshwater & Cymbella sp., Pennat diatom \\
\hline 28 & Şile Coast & Sea & \\
\hline 29 & Eyüp Coast & Sea & Pennat diatom, Bdelloid Rotifer \\
\hline 30 & Tekirdağ Coast & Sea & \\
\hline
\end{tabular}

Cytbella sp., Navicula sp., Amphora sp., Gomphonema sp., Pleurosigma sp., Surirella sp., Diploneis sp., Diatoma sp. of the class Fragilariophyceae and Synedra sp., Melosira sp. of the class Coscinodiscophyceae diatoms and Prorocentrum micans plankton of the class Dinophyceae were determined and microscope images were shared.

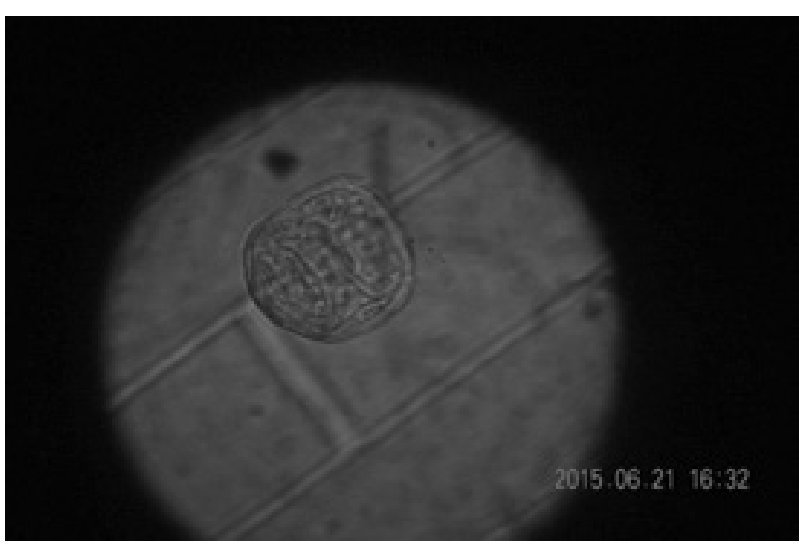

Figure 2. Lung tissue from the case no. 4, Melosira sp.

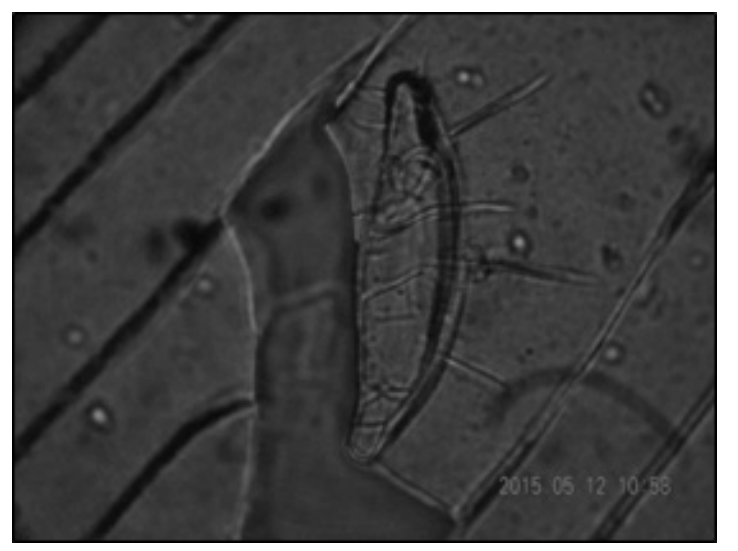

Figure 3. Stomach content from the case no:10, Cymbella sp. 


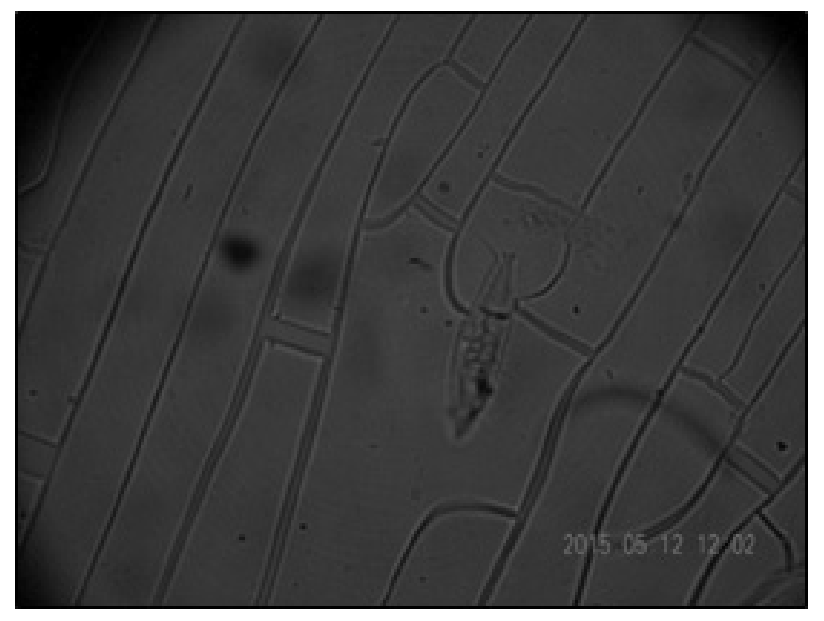

Figure 4. Lung tissue from the case no:10, Amphora sp.

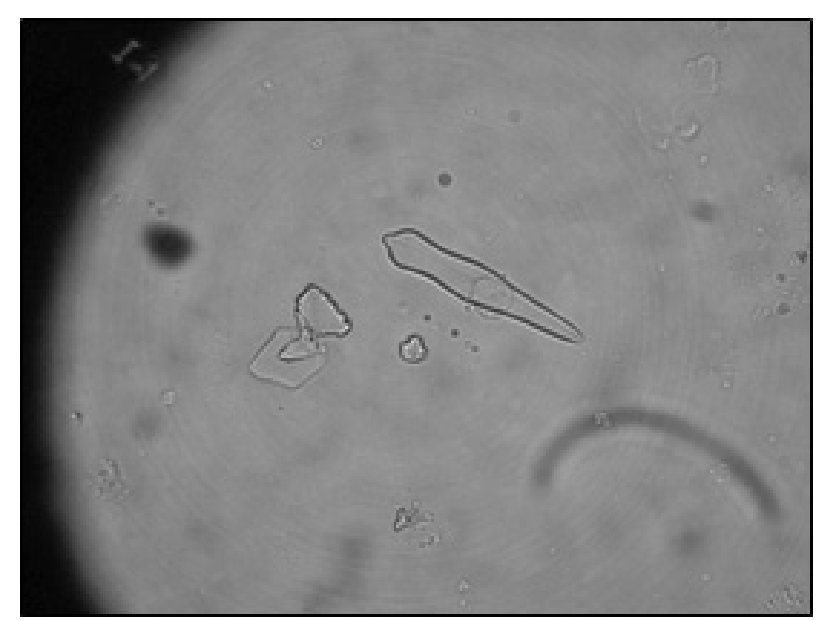

Figure 5. Intranasal swab from the case no:10, Gomphonema sp.

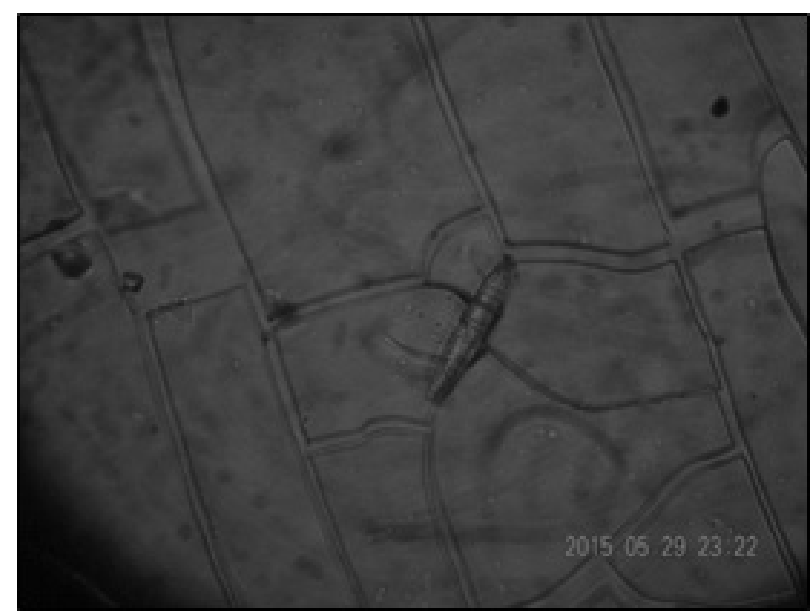

Figure 6. Lung tissue from the case no:11, Diatoma sp.

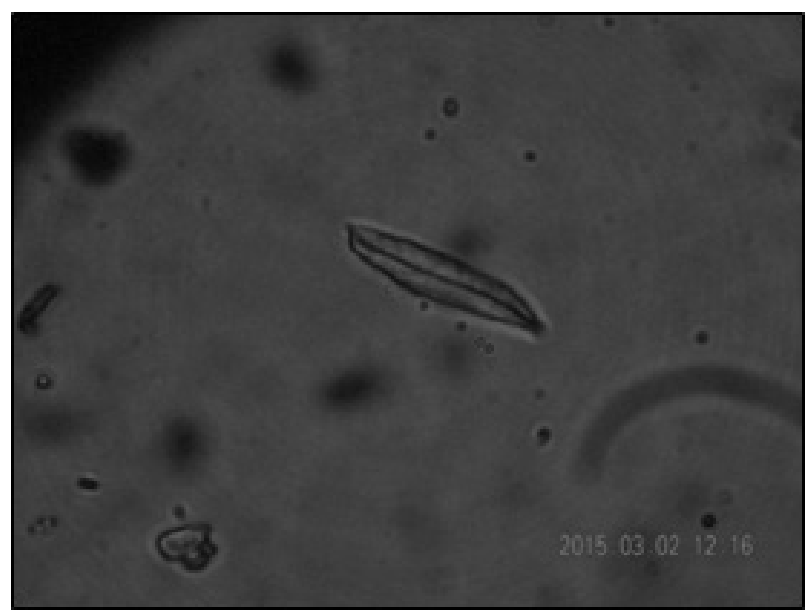

Figure 7. Renal tissue from the case, no:13, Pleurosigma sp.

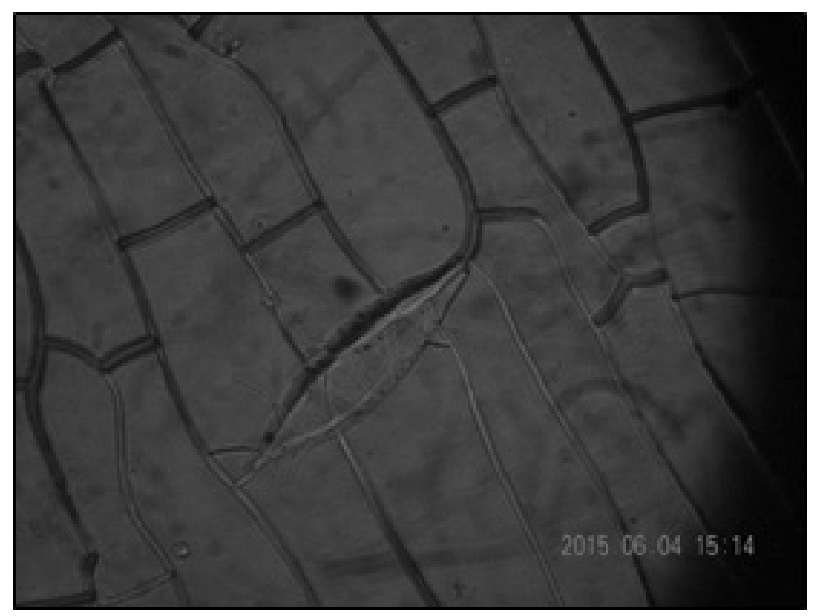

Figure 8. Lung tissue from the case no:18, Navicula $s p$.

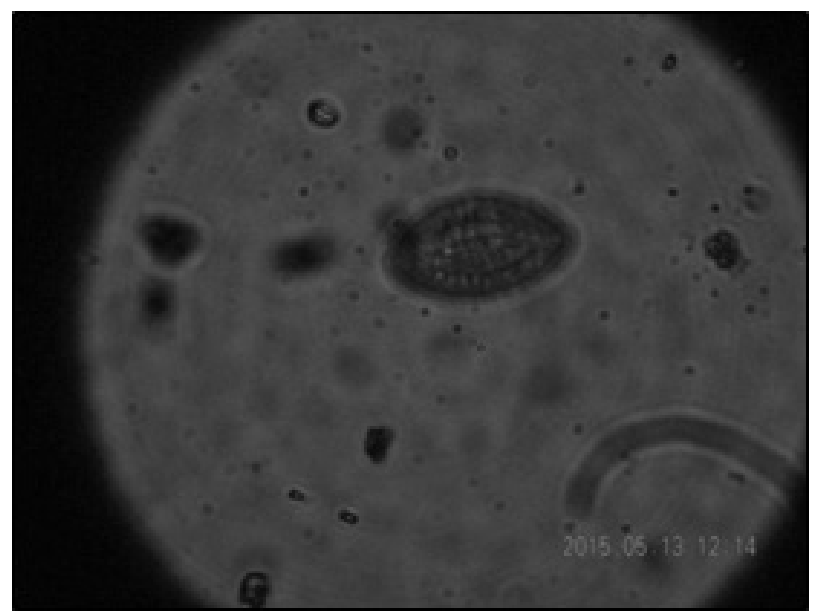

Figure 9. Lung tissue from the case no:19, Surirella $s p$. 


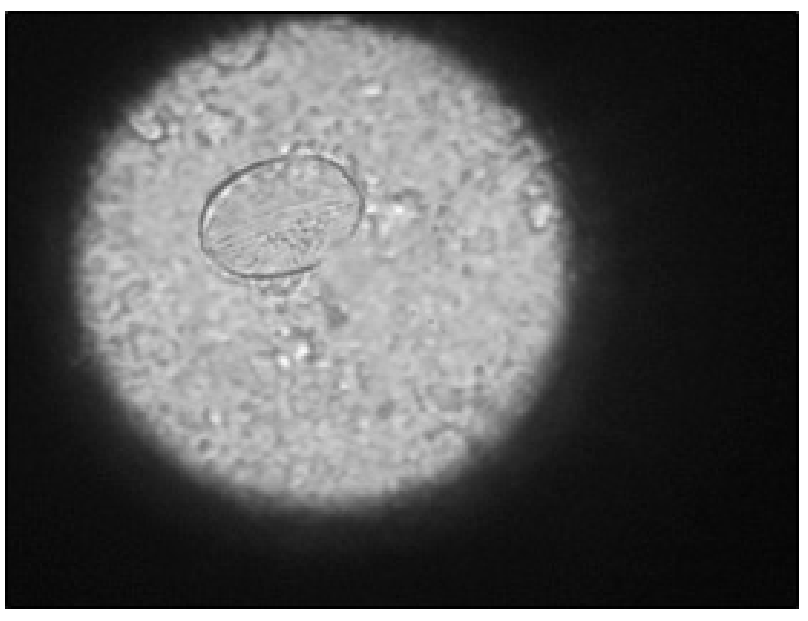

Figure 10. Intranasal swap from the case no:21, Diploneis sp.

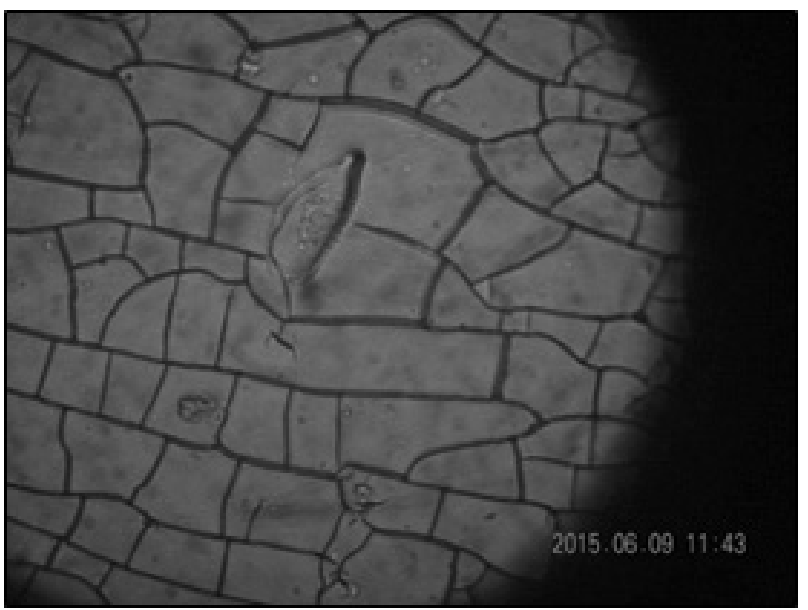

Figure 11. Lung tissue from the case no:22, P. micans.

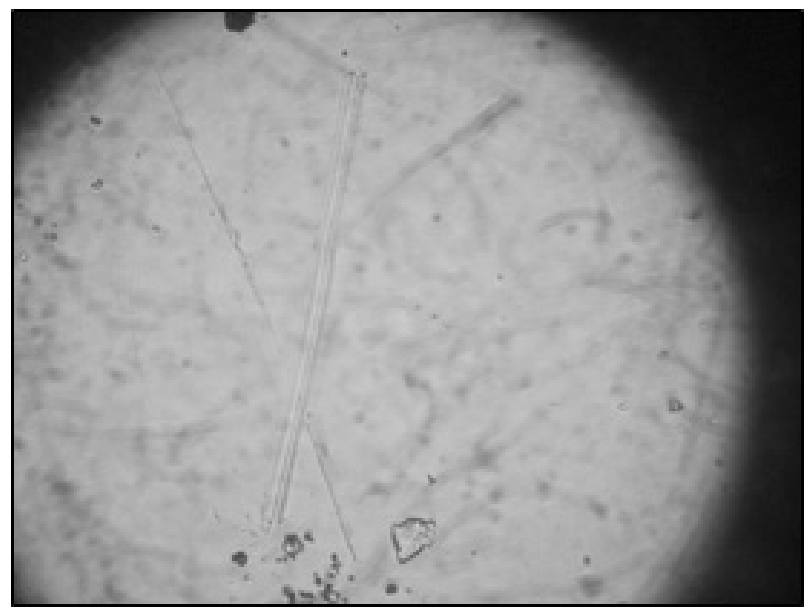

Figure 12. Umbilicus swap which is removed from the case, Synedra sp.

Internal organ and body fluid samples of the corpses removed from water were examined and how many diatoms were detected from which tissue or liquid was summarized in Figure 13.

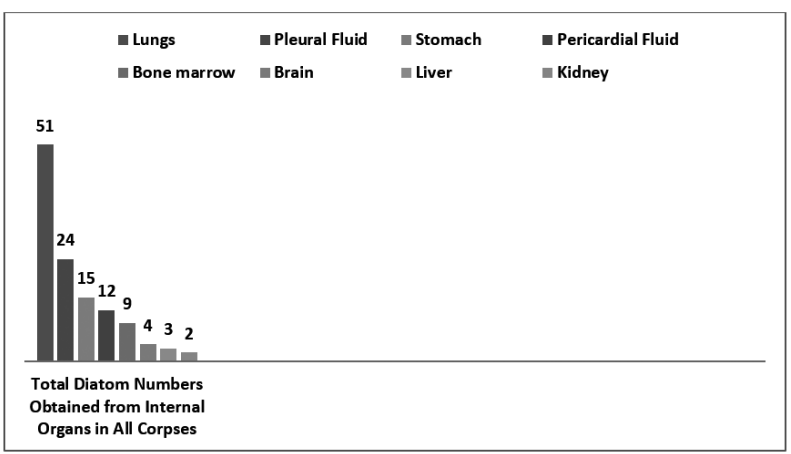

Figure 13. Total diatom numbers obtained from internal organs in all corpses

Table 2. Diatom numbers obtained from swab samples taken from the outer surfaces of corpses.

\begin{tabular}{|c|c|c|c|c|c|c|c|c|}
\hline $\begin{array}{c}\text { No of } \\
\text { Case }\end{array}$ & $\begin{array}{c}\text { Intra- } \\
\text { oral }\end{array}$ & $\begin{array}{c}\text { Intra- } \\
\text { nasal }\end{array}$ & $\begin{array}{c}\text { External Ear } \\
\text { Canal }\end{array}$ & Hair & $\begin{array}{c}\text { Fossa } \\
\text { axilarris }\end{array}$ & $\begin{array}{c}\text { Umbilical } \\
\text { folds }\end{array}$ & $\begin{array}{c}\text { Interphalangeal } \\
\text { areas of foot }\end{array}$ & Perineum \\
\hline 10 & 2 & 14 & - & 6 & 1 & - & 1 & - \\
\hline 12 & - & - & 2 & - & - & - & - & - \\
\hline 16 & - & - & 1 & - & - & - & - & - \\
\hline 21 & - & 5 & - & - & - & 1 & - & - \\
\hline 22 & - & - & - & & 1 & 2 & - & - \\
\hline 23 & - & - & 1 & - & - & - & - & - \\
\hline 27 & - & 1 & - & - & - & - & - & - \\
\hline 29 & - & - & - & 1 & - & - & - & - \\
\hline
\end{tabular}


The results of the examination of the diatoms obtained from the swab samples taken from the outer surfaces of the corpses are summarized in Table 2.
The diatoms obtained from the internal organs of the bodies and the diatoms obtained from the external surfaces of the bodies were compared and the microscope images of them were shared in Figure 14-18.
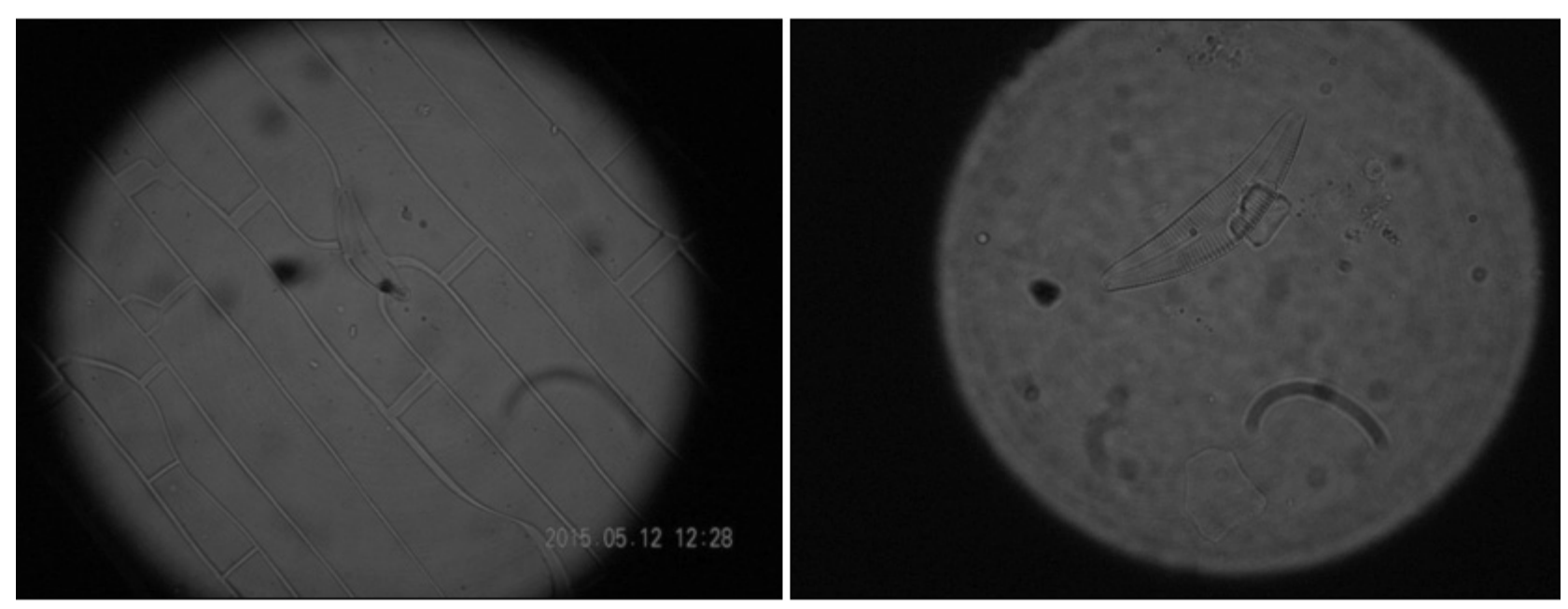

Figure 14. Lung tissue of the case, no: 10, Cymbella sp. and intranasal swap, Cymbella sp.
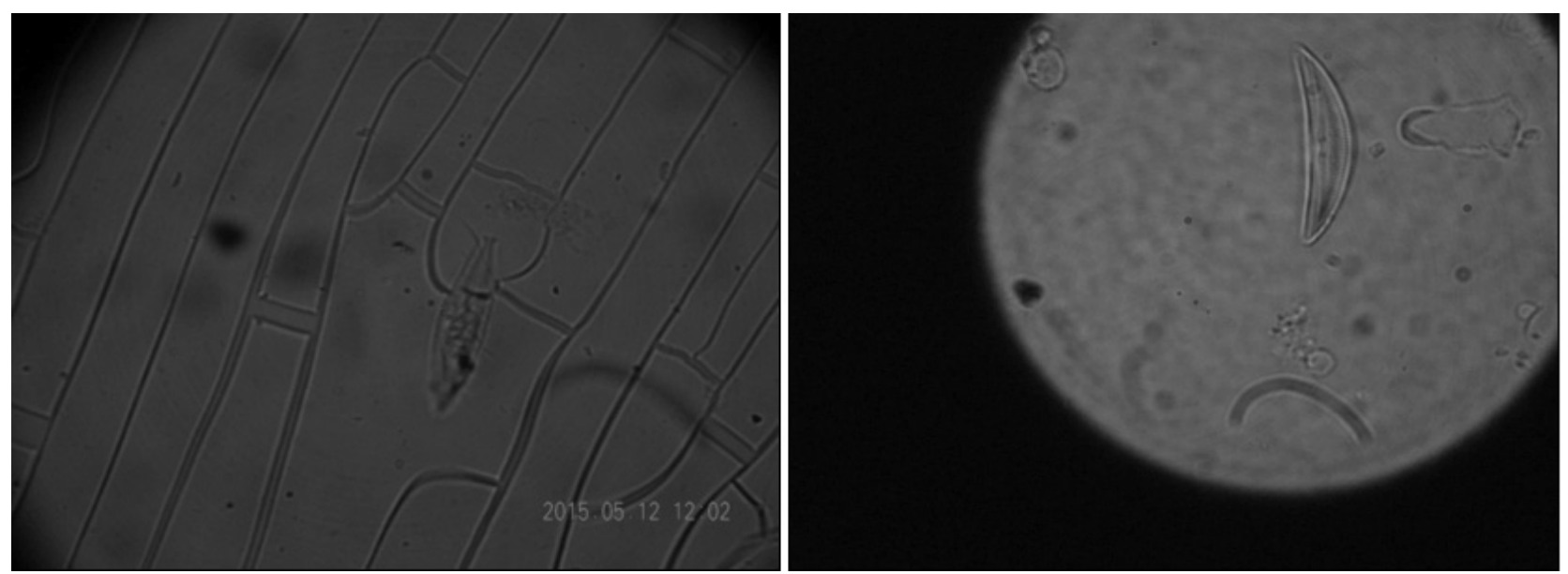

Figure 15. Lung tissue of the case, no: 10, Amphora sp. and intranasal swap, Amphora sp.
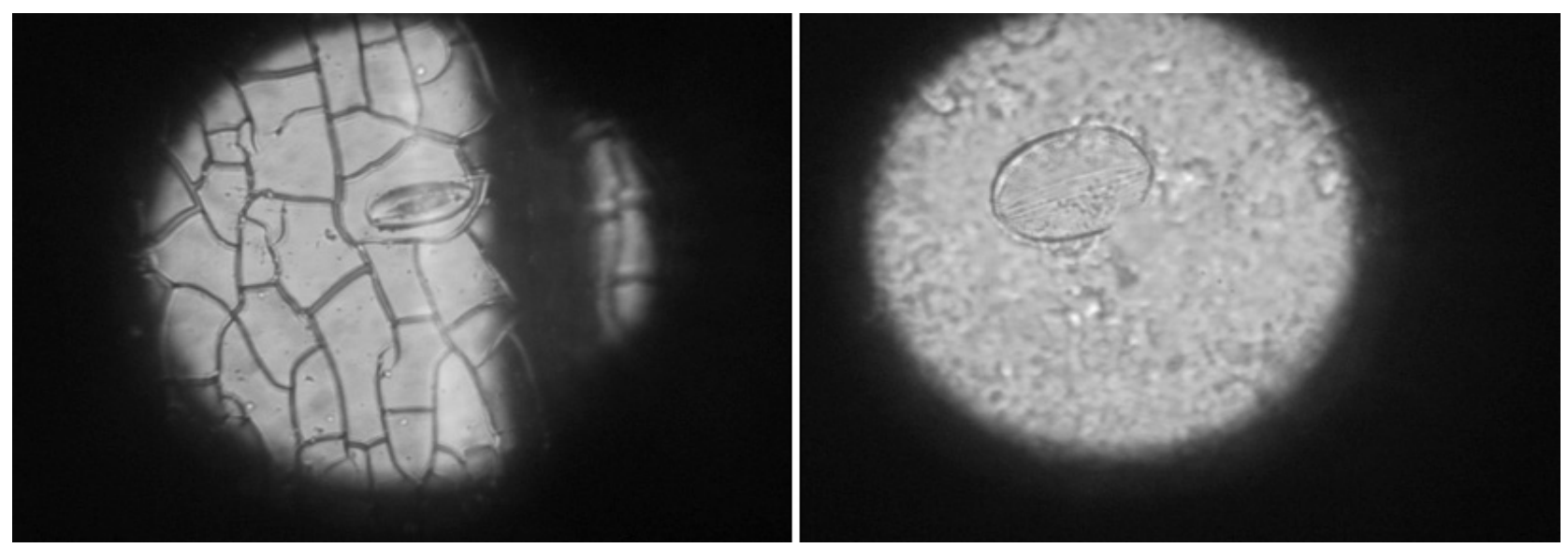

Figure 16. Stomach contents of the case, No:21, Pennat diatom and intranasal swap, Diploneis sp. 


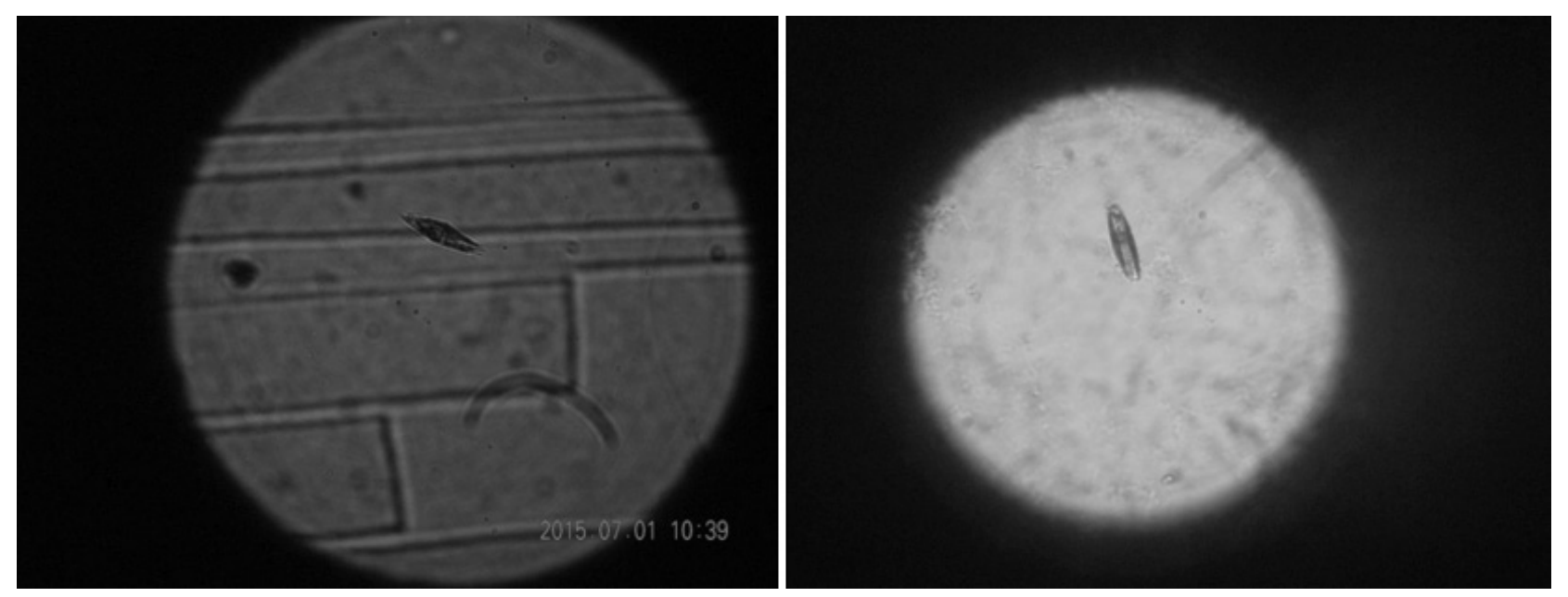

Figure 17. Pleural fluid of the case No:23, Pennat diatom and in-ear swap, pennat diatom.
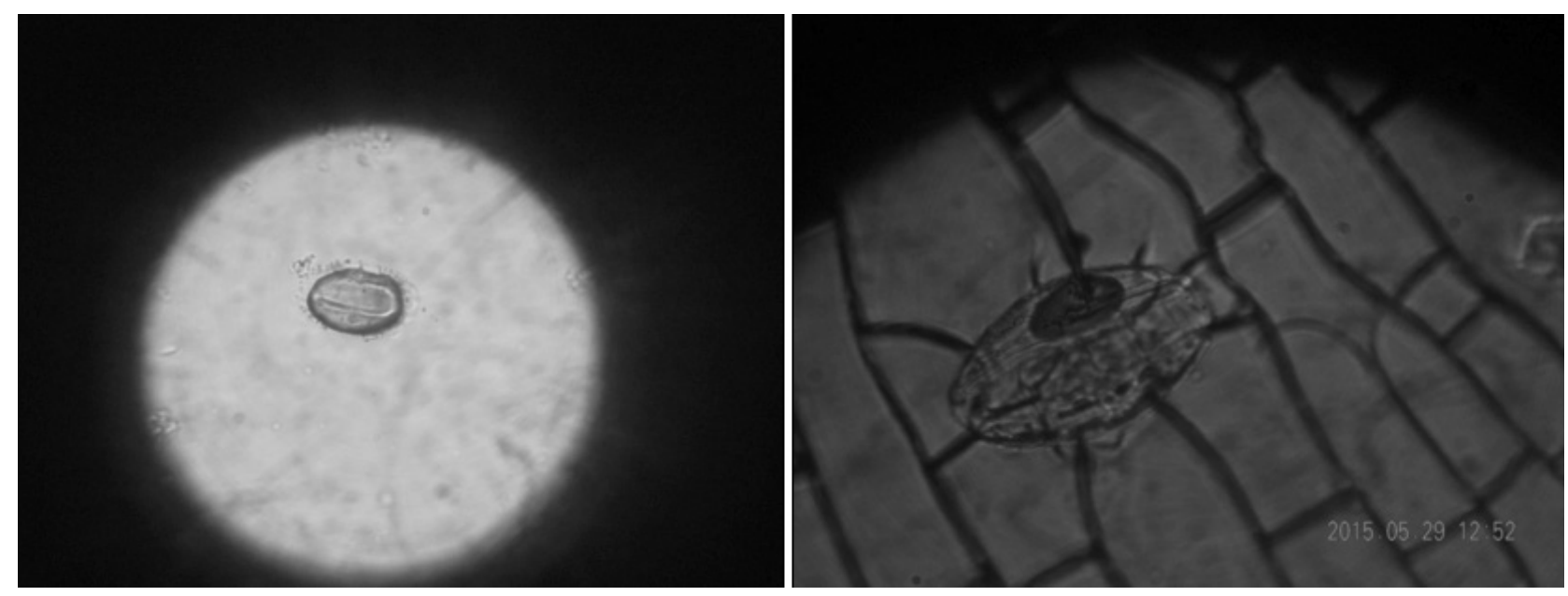

Figure 18. Fossa axilarris swap of the case:10, Pennat diatom and stomach contents of the case no:11, Amphora sp.

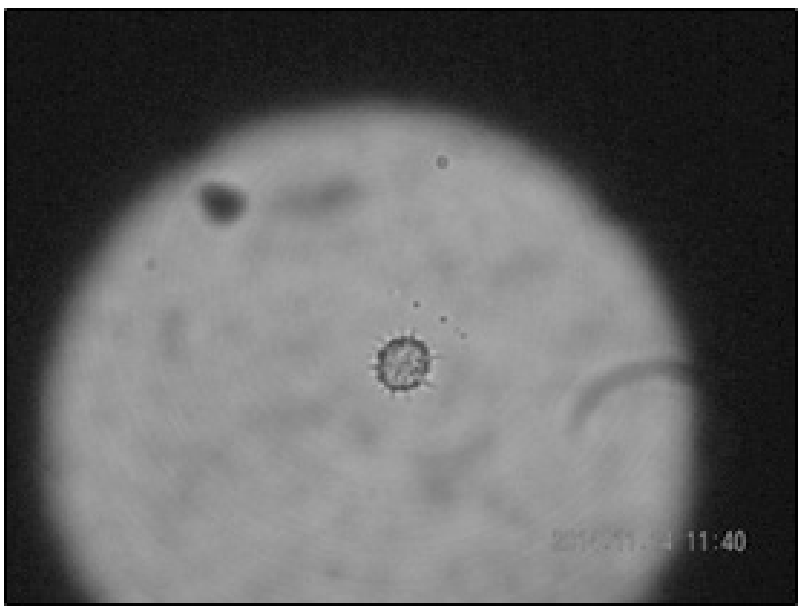

Figure 19. Dinoflagellate cyst from lung tissue of the case no: 1
Plankton images which are obtained from other than diatom the tissue samples of 3 cases other than diatom were shared in Figures 19, $20,21$.

\section{Discussion}

Between June 2014 and August 2014, 30 corpses which were pulled out of water taken to autopsy in the "Republic of Turkey, Ministry of Justice, Forensic Medicine Institute, Morgue Specialization Department" is included in our study.

There were reports that 29 cases of a total of 30 cases have declared death was the result of drowning. For the case of 1, a report was issued with the forensic investigation file regarding the cause of death, with the opinion that it is appropriate to seek the opinion of the "First Specialized Board of Forensic Medicine" 

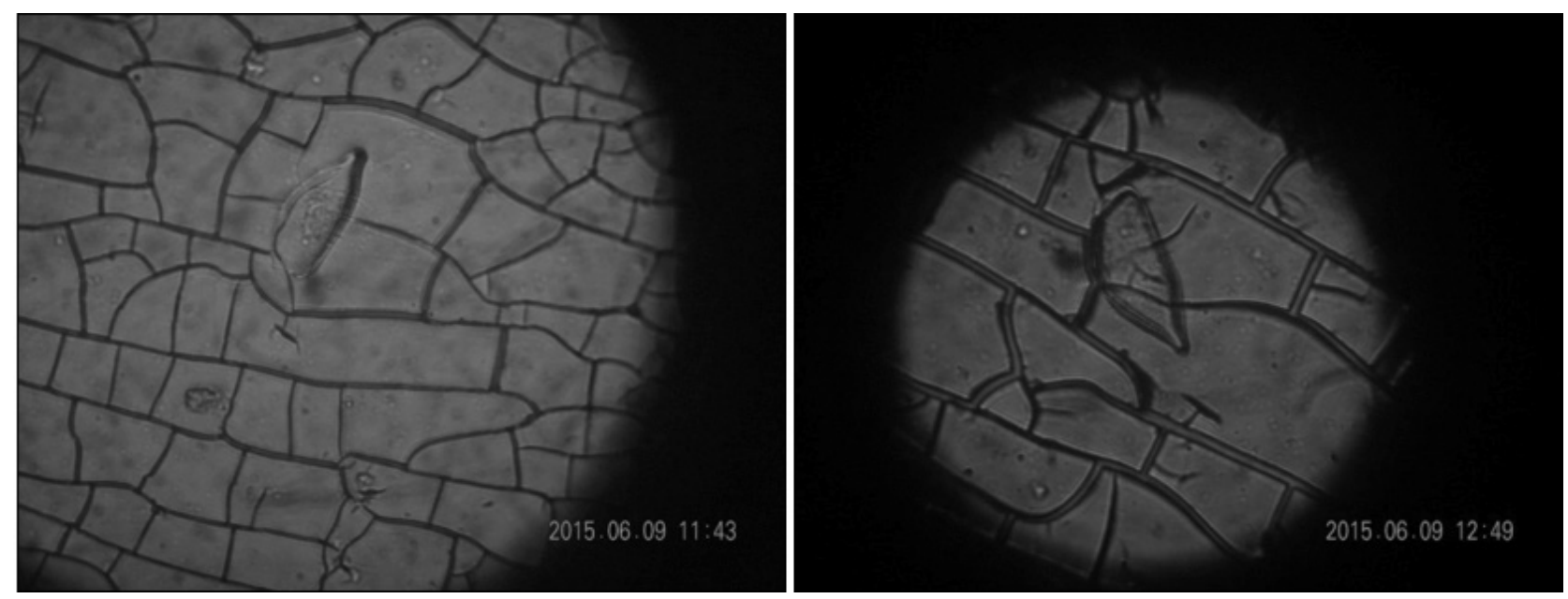

Figure 20. Prorocentrum micans obtained from the lung tissue of the case no: 22

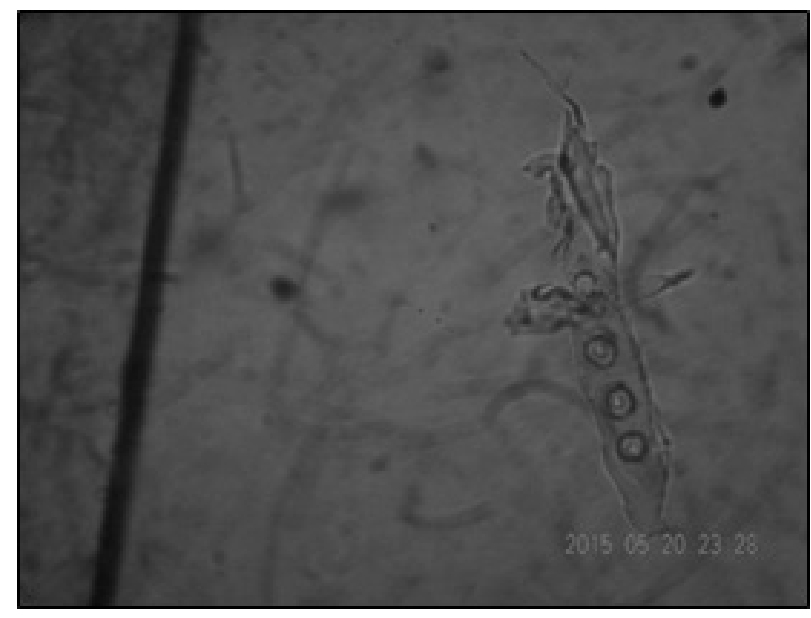

Figure 21. Bdelloid Rotifera obtained from lung tissue of case no:29

Yorulmaz (1996), between December 1994 and November 1995, has examined 100 cases which were proven to drown in water sent to the Republic of Turkey, Ministry of Justice, Forensic Medicine Institute, Morgue Specialization Department for autopsy process. The researcher has reached the conclusion in 83 of 100 cases $(83 \%)$ diatom $(+)$ and in the remaining 17 cases $(17 \%)$ diatom (-) as a result. In addition to the quantitative examination, the qualitative determination of diatoms and their comparison with the water obtained from the environment will support the diagnosis and conclude that the forensic examination will be carried one step up from the quantitative diatom test (8).

Kumral et al. (2010), records of autopsies performed within the period of 5 years covering the period between 2003 and 2007 in the Forensic Medicine Institute, Morgue Specialization Department were retrospectively reviewed. In 300 of 433 cases, diatom analysis has resulted as negative (-). The negative rate was found to be approximately $70 \%$. In order to evaluate all factors such as contamination and intimidation, it has been concluded that the use of diatoms in the diagnosis of asphyxiation should be reviewed by prospective, controlled studies which will evaluate them comparatively with the samples belonging to the suffocation environment by using the different methods used in diatom analysis (9).

In comparison to the diatom test results, In the corpses pulled out of water, according to the diatom positive cases, Ludes and Coste (1996), 40 cases, in 14 cases, diatom $(+)$, and in 11 cases, diatom $(+)$ were found in both lungs and other organs (liver, kidney, or brain). Diatom (-) was detected in 15 pATIENTS. IN ANOTHER STUDY CONDUCTED BY AUER AND MATTENEN (1988), ONLY 33 OF 107 CASES WERE DIAGNOSED AS DIATOM $(+)$ IN LUNG TISSUE, 62 CASES WERE DIAGNOSED AS DIATOM $(+)$ in lung and other organs. In 12 cases, no diatoms were found (10).

Cases of drowning in dry water where there was not liquid aspiration at all and in the presence of factors such as heart failure, lung disease, alcohol, which have an accelerating effect of death because of the lack of liquid aspiration, even if there is enough diatoms in the water, insufficient or wrong negative results can be obtained (11).

In the case of diatom negative cases, Angelini Rota (1960) examined 48 cases and $24.2 \%$ of them were not detected diatom in the lung and $32.6 \%$ of them had been diatom (-) in other organs. Similarly, Neidhart and Greendyke (1967) reported these values as $17 \%$ and $30.8 \%$ respectively. Timperman (1969) found no diatoms in $10 \%$ of 40 cases in lung tissue. Auer and Mattönen (1988) found no diatoms in the lungs and other organs in 
$11.2 \%$ of the cases. In a similar study, Ludes and Coste reported this rate as $37.5 \%$ (10).

Timperman (1969) reported cases known to have died as a result of drowning in water which had diatoms in other organs in spite of this, the researcher has mentioned cases with no diatoms in their liver (12). In this study, diatom was detected in only 2 cases of liver tissue. it has been observed that the homogenization method used is inadequate in making the liver tissue fully homogenized. it was thought that if the tissues were fully homogenized with the help of automatic homogenizer, better results could be obtained.

In this study, when the diatoms obtained from tissues are examined in terms of shape, it was determined that almost all of them were composed of pennate diatoms. It was concluded that the diatoms in this form were easily penetrated into the tissues. Sitthiwong et al. (2011) support this idea as a result of their work (13).

In the study of Yorulmaz (1996), it was observed that the number of negative results in June and July was high. Although the number of diatoms in seawater varies from shore to shore during the months when water is heated, it is stated that the number of diatoms in seawater has been reduced to very low or even completely lost (8). In this study, it can be explained that the diatom numbers obtained from internal organs, body fluids and external surfaces are low, and all of the cases are corpses removed from the water in June-August.

The most common method used to obtain diatom from internal organs, which supports the diagnosis of drowning in water, is the acid treatment of tissues, because of the strong effect of acid, it is impossible to detect the plankton outside diatom. Terazawa (1980) reported that with colloidal silica gradients, plankton can be obtained from the lungs of drowned patients, and Percol usage is a quick and practical method to obtain plankton from tissues (14). Abe et al. (2003), with the newly developed PCR method, they obtained plankton from the tissues and blood of aquatic victims using Percol (6).

In this study, lung tissue samples in the case no:1, no:22 and no:29 obtained from Dinoflagellates cyst (Figure 19), Prorocentrum micans (Figure 20) and Bdelloid Rotifer (Figure 21), the method was successful in the tissues of the plankton of the advantage of the method in terms of detection and revealed that he has added value by showing an extra work. Prorocentrum micans redtide, known as the popular name, is a species of plankton, which causes characteristic excessive reproductive activity by turning the sea color red (15).

Diatoms collected in sediment along Geological cycles are found in two different structures. The first is the kiesliguhr, which shows itself in the form of mud in the form of silicate amorphous masses. The other is diatomite, which sometimes finds kilometers in length, with a more compact structure, chalk, easily broken and slightly attracted to the appearance of White Rock. Both types were submerged in geological cycles, but today they have landed with tectonic movements. Kieselguhr and diatomite are the preferred materials for dampening and removing as they are used for sound and heat insulation. Also used in diatomite, beer and swimming pool filters, cosmetics industry, toothpaste and even in the construction of dynamite with kieselguhr (15).

Diatom, which is located in many areas of industry as filtration, insulation, filling material and abrasive, is known to be used as a building material in ancient Rome and Greece. In addition, it is known that the It was also used in the dome construction of Hagia Sophia church as instructed by Emperor Justinianus to the architects (16).

The reliability of the diatom test in cases of drowning in water is discussed in terms of the presence of diatom in the body and internal organs as a result of the antemortem contamination. However, it can be said that the plankton other than diatom is much more useful in diagnosing asphyxiation in water because it is not possible to have antemortem contamination (17).

At the same time, two corpses removed from the same water environment, case no:10. and 11, diatoms were examined, which are obtained from the internal organs and external surfaces. From case no: 11 which was the outer surface of the swab sample not available, diatoms obtained from the stomach and lung and diatoms obtained from intra-nose, Inter-toe and Fossa axillaries samples from case no: 10 was found that they had the same type as the diatoms. This is thought to be a good example of the appearance of the sway samples taken from the surface to represent the suffocation environment (Figure 18).

For the extraction of diatoms in cotton T-shirt soaked in water containing diatom, Scott (2014) treated sample of t-shirt with $\mathrm{H}_{2} \mathrm{O}_{2}$ diluted by $30 \%$ and waited 3 hours in the hot water bath at $70^{\circ} \mathrm{C}$ and then centrifuged the solution at $1200 \mathrm{rpm}$ (18). Since swaps were also cotton material, the same method was followed in swaps analysis and it was concluded that $\mathrm{H}_{2} \mathrm{O}_{2}$ usage was highly appropriate in terms of diatom number and variety.

A large number of diatoms were obtained from the looming samples taken from the nose compared to other samples. It is thought that the nasal remains more protected and moister than the other areas. The fact that all the victims wore underwear or swimwear was considered to be the reason why no diatoms were obtained from the perineum samples. 


\section{Conclusion}

In the corpses extracted from water, one of the tests that help to diagnose drowning in water is the Diatom test. In this study, diatom was successfully obtained from the internal organs of the corpses by using Colloidal Silica Gradient centrifuge method instead of a conventional Nitric Acid Method, which is a common use of the tissues to obtain diatoms by dissolving them with acid. The study shows the advantages of the method in terms of non-toxic, reliability, ease of application and the availability of non-diatom plankton from the tissues.

The diatoms obtained from the swab samples obtained from the external surfaces with the help of Swab rods were compared with the diatoms obtained from the internal organs and it was concluded that the swab samples obtained from the nose represent the drowning environment in terms of both quantity and variety.

Support Resources: This study was funded by Istanbul University with the project number 38022

\section{References}

1. Yorulmaz C. Sudan Çıkarılan Cesetler, Adli Tıp Ders Kitabı 2011, Cerrahpaşa Tıp Fakültesi Yayın no:281, s. 217-233

2. Kumar A, Malik M, Kadian A. Role Of Diatom Test in Forensic Science For Examination Of Drowning Cases, Report And Opininon 2011, 3(9).

3. Krstic S, Duma A, Janevska B, Levkov Z, Nikolova K, Noveska M. Diatoms in Forensic Expertise of Drowninga Macedonian Experience, Forensic Science İnternational 2002, 127:198-203.

4. Piette MHA, De Letter EA. Drowning: Still a Difficult Autopsy Diagnosis, Forensic Science International 2006, 163: 1-9.

5. Singh R, Thakar MK. Extraction Methods Of Diatoms-A Review, Indian Internet Journal Of Forensic Medicine And Toxicology, 2006, 4(2).

6. Abe S, Suto M, Nakamura H, Gunji H, Hiraiwa K. A Novel PCR Method For Identifying Plankton In Cases Of Death By Drowning, Medicine, Science \& The Law, 2003, 43: 1
7. He F, Huang D, Liu L, Shu X, Yin H, Li X. A Novel PCRDGGE-Based Method For Identifying Plankton 16S rDNA For The Diagnosis Of Drowning, Forensic Science International 2008, 176:152-156.

8. Yorulmaz C.(1996),Suda Boğulma Tanısında Diatom Testinin Değeri, Uzmanlık Tezi.

9. Kumral B, Büyük Y, Fidancı G, Cun E, Özbay M, Cenger CD ve ark. İstanbul'da Otopsisi Yapılmış Suda Boğulma Sonucu Ölüm Olgularında Diatom Varlığının Değerlendirilmesi, Adli Tıp Dergisi 2010, Cilt 25, Say1 1, S 33-40.

10. Lunetta P. Bodies Found In Water, Epidemiological and Medico-lagal Issues, Academic Dissertation, 2005, Helsinki.

11. Yorulmaz C, Çakalır C, Suda Boğulma, İ.Ü. Cerrahpaşa Tıp Fakültesi Yayınları, Adli Tıp, İstanbul, 1999, Cilt 1, Sayfa: 459-474.

12. Timperman J. Medico-Legal Problems in Death by Drowning(Its Diagnosis by The Diatom Method), Journal of Forensic Medicine 1969, 16(2);45-47.

13. Sitthiwong N, Ruangyuttikarn W, Vongvivach S, Peerapornpisal Y. The Study of Diatoms in Drowning Corpses, Journal of the Microscopy Society of Thailand 2011, 4(2):8488

14. Terezawa K, Takatori T. Isolation Of Intact Plankton From Drowning Lung Tissue By Centrifugation In A Colloidal Silica Gradient, Forensic Science International 1980, 16: 63-66.

15. Koray, T. Denizel Fitoplankton, Ege Üniversitesi Su Ürünleri Fakültesi Yayınları, No:32, 2002, Bornova, İzmir, ISBN: 975-483-545-4.

16. McLaughlin RB. An Introduction To The Microscopical Study Of Diatoms, Edited by John Gustav Delly\&Steve Gill 2012, USA\&United Kingdom

17. Kobayashi M, Yamada Y, Zhang W, Itakura Y, Nagao M, Takatori T. Novel Detection of Plankton From Lung Tisssue by Enzimatic Digestion Method, Forensic Science International 1993, 60: 81-90.

18. Scott KR, Morgan RM, Jones VJ, Cameron NG. The Transferability Of Diatoms To Clothing And The Methods Appropriate For Their Collection And Analysis In Forensic Geoscience, Forensic Science International 2014, 241:127137. 